\title{
THE MEDIATING EFFECT OF WORK ENGAGEMENT ON THE RELATIONSHIP BETWEEN TOTAL REWARD PERCEPTIONS AND EMPLOYEE RETENTION
}

\author{
K.J.M. Fernando \\ FairFirst Insurance Limited \\ Colombo \\ jayanifernando224@gmail.com \\ H.M. Nishanthi \\ Faculty of Commerce and Management Studies \\ University of kelaniya. \\ menaka@kln.ac.lk2
}

\begin{abstract}
The current study investigates the impact of total reward perceptions on employee retention with the mediating effect of work engagement of executive-level employees in the Sri Lankan insurance industry. Data were collected employing a structured questionnaire utilizing simple random sampling technique. The sample consisted of 196 executive-level employees working in three general insurance companies. Simple linear regression analysis is used to test the direct relationships that exist between the variables, while the mediating impact was tested using the Sobel test. Results revealed a significant effect of total reward perceptions and work engagement on employee retention. The mediation of work engagement is also partially supported. Hence, the study extends the existing literature in work engagement, revealing its mediation effect on the relationship between total rewards perceptions and employee retention. Results obtained direct the companies to pay attention to the total rewards perception in terms of monetary, material, and non-monetary rewards in building a more engaged workforce. Appropriate rewards are essential for retaining and engaging employees in the organizations for a prolonged period of time.
\end{abstract}

Keywords: Total rewards perceptions; Work engagement; Employee retention, Insurance industry 


\section{Introduction}

Today, the labour market has developed and entered a new era with innovation, knowledge development, globalization, and increased competition (Sheehan, 2012). In this competitive business environment, employee retention has become a real challenge as employers now begin to realize the value of the employees in their organizations (Dhanalakshmi, Gurunathan\& Vijayakumar, 2016). The main goal of employee retention is to prevent competent employees from leaving the organization (Bansal, 2014). However, research has shown that it is quite easy to recruit people, whereas retaining them is much more challenging (Fahim, 2018). According to Ross (2012), the retention war starts at the recruitment stage, where the employers will look for employees whose talents and interests match the organization's short-term and long-term needs. Hence, retention can be a complex concept, and there is no single way to keep the employees with the organizations (Sinha \& Sinha, 2012).

A critical area in human resource management that has been seen to affect an employee's motivation to join, learn and stay with an organization is compensation and rewards (Medcof \& Rumpel, 2007). Employees want to be appreciated for their efforts in work and expect a fair return for that effort. Total rewards is a new deviation of rewards as it includes "everything that employees value in the employment relationship” (O’Neal, 1998, p. 6). It consists of financial rewards such as salary, incentive pay, stock options and benefits and non-financial rewards such as training and growth opportunities, challenging work, feedback and appreciation for work and work arrangements that support work-life balance (Heneman \&Tansky, 2002; Medcof\&Rumpel, 2007). However, according to De Gieter, De Cooman, Pepermans, Caers, Du Bois and Jegers, (2006) total rewards include three categories such as financial rewards, material rewards, and psychological rewards. Financial rewards include all monetary payments, material rewards include benefits, training and growth opportunities and other category includes psychological rewards such as recognition. Hence, the total rewards system is seen as a way of enriching rewards and recognition practices that help employee well-being and organizational performance (JiangJiang, Xiao, Qi \& Xiao, 2009; Hulkko-Nyman,Sarti, Hakonen \& Sweins, 2012). 
In organizational reward model, employee engagement is seen as a driving force that encourages employees' positive attitude at work which helps the employees to overcome stress and burnout and feel happy for completing the assigned task at the workplace (Saks, 2006; Crawford, Rich, Buckman \& Bergeron, 2014). The very first conceptual definition for engagement was by Kahn (1990, p. 700). It explains engagement as "as an expression by an individual of his/her "preferred self" simultaneously in task behaviors that promote connections to work and to others personal presence (physical, cognitive and emotional) and active full role performances". According to Albrecht (2010, p. 4), engagement is "a positive work-related psychological state characterized by a genuine willingness to contribute to organizational success". The total rewards perspective can be seen as a way of building an engaged workforce because employees expect a fair return for the time and effort they put in completing an assigned task. Hence, this study is conducted to identify the influence of the total rewards perspective in retaining the employees with the mediating impact of work engagement with special reference to the Insurance industry in Sri Lanka.

The insurance industry is seen as one of the most dynamic sectors in Sri Lanka from time immemorial. Recently, this industry has shown rapid development and growth with an overall gross written premium of Rs. 181,506.00 million for life and general insurance business (IRCSL Annual Report, 2018). As a service-oriented business, hiring and retaining competent employees has become a competitive advantage for insurance companies (Das, 2016). Accordingly, employee retention has become a major issue for HR managers (Kumar \& Clerk, 2020) as the labour turnover in this sector is approximately 20\% (Mendis, Silva \& Mitsuhashi ,2009).

\section{Problem Justification}

Employee retention is one of the prominent areas of research in human resource management literature, and many studies are carried out on the same. Most of the studies were conducted taking in to consideration the variables such as talent management practices ( Dhanalakshmi et al.,2016; Boustani \& Chitsaz-Isfahani, 2014), supportive work environment (Kundu \& Lata,2017), perceived training and development (Alfes, Fletcher \& Robinson, 2018), Organization citizenship 
behavior (Paillé, 2013) , quality of work-life (Agus\& Selvaraj,2020) and organizational commitment (Gregory, Redditt \& Ro,2019) with employee retention. However, empirical research does not give a sufficient relationship of total rewards with work/organizational outcomes like employees' intention to stay (Rai, Ghosh, \& Dutta,2019).

Gamage and Jayatilake (2017) had conducted a study on the impact of job satisfaction and organizational commitment on employee retention in Sri Lankan insurance companies. However, most of the studies on employee retention were on the Information Technology industry (Thite, 2010; Alais, 2013; Dhanalakshmi et al.,2016), the banking sector (Ali \& Mustafa,2019; Rai et al., 2019 ), education sector (Akhtar, Aamir, Khurshid, Abro\& Hussain, 2015) and several other industries. According to Peluso, Innocenti and Pilati, (2017) as monetary and non-monetary rewards have rarely been considered together from the human resource perspective; there is still a lack of studies that discuss the relationship between the adoption of a total reward system and employee-related outcomes. According to Hulkko-Nyman et al. (2012), the association of total rewards with work engagement is less identified in the literature. Hence, it is visible that there is a dreath of published articles examining the relationship between total rewards perspective and employee retention with the mediating effect of work engagement.

When addressing the empirical gap, according to a study done by Rasika (2018) surveying life insurance agents in Sri Lanka, there is a low retention rate in this industry. It has also been found that the insurance sector has the highest employee turnover at the level of insurance agents (Pattanayak \& Chhabra, 2014). The insurance industry worldwide faces a major issue of high turnover, and employees retention has been a persistent issue for HR managers (Kumar \& Clerk, 2020). It is noted that the high employee turnover in the insurance industry is because of the employees are rotating within the industry; therefore, organizations are losing the employees to their direct competitors (Mendis et al., 2009). According to Gamage and Jayatilake (2017), the number of studies conducted on the insurance industry is lesser in the Sri Lankan context. Hence, it is crucial to research this industry as employee retention could be seen as a critical issue in the insurance industry. 
Furthermore, analyses of employee retention strategies are carried out from a developed country perspective (Ahammad, Glaister, Weber, \&Tarba, 2012). However, it is crucial for the success of any organization to establish an efficient employee retention system to ensure that key employees or talents remain within the organization (Earnest, Allen, \& Landis, 2011; Gavino, Wayne, \& Erdogan, 2012). Hence, this study aims to enrich literature and extension of knowledge in this field.

To better identify the existence of the research problem, a pilot study was conducted to verify whether there is an impact of total rewards perceptions on employee retention. A survey was conducted among 25 employees using the questionnaire developed in the study. As per the responses, 14 employees have answered that they are not happy to stay with the organization for a more extended period. Six employees have shown interest in being committed to the company, and three have provided moderate responses. The results revealed that there is an issue of employee retention within the insurance industry. Hence, this study focuses on identifying "whether there is a mediation impact of work engagement on the relationship between total reward perceptions and the retention of the executive level employees in the insurance industry of Sri Lanka."

The following are the research objectives to be achieved to address the above problem.

1. To identify the impact of total reward perceptions and work engagement on the retention of the executive level employees in the insurance industry of Sri Lanka

2. To identify the mediating effect of work engagement on the relationship between total reward perceptions and retention of the executive level employees in the insurance industry of Sri Lanka

The study's findings contribute to the practice gap prevailing in the industry as to how to use total reward perceptions to retain and engage the employees working in the insurance industry. The results enable all the companies to redesign their employee retention strategies using total reward perceptions that benefit both the employees and the employers. The employees will receive a fair return for the effort they make in the job, and the employers will be able to retain the talented 
and skilled employees with them for a longer period. Additionally, insurance companies can gain a competitive advantage while maintaining organizational performance, morale, and positive customer retention.

The study also addresses the literature by investigating how the organizations' reward systems enhance the level of engagement of their employees and how that engagement in work would help attach the employees to their employers. Therefore, it will bridge the gap in human resource management literature about the relationship between total rewards perceptions, work engagement and employee retention in the insurance industry. As this study generates new knowledge in the insurance industry testing the relationship between the aforementioned variables, individual researchers can use this research and further develop the study into different sectors.

\section{Literature Review and Hypotheses Development}

Even though the technology is advancing rapidly day by day, there is a considerable demand for human skills. As insurance is a service industry, knowledge is essential and retention of talented employees is critical for any organization's progress. However, as employees working in this industry is dealing with high levels of stress with demanding or challenging clients, the employees' ability to survive in the insurance business and to achieve their career goals, time pressures and meeting deadlines, working continually to achieve targets, the mental strain of work and workload, employee retention is a major concern in this industry.

When there is a low retention ratio, it indicates that the employees will not remain in the organization for a more extended period (Gamage \& Jayatilake, 2017). Hence, the employers have to recruit new employees, and there is a significant cost involved in attracting, training, and engaging these new employees. Low retention is not new (Bibi, Ahmad \& Majid, 2018) as it has always been a challenge for employers (Mathimaran \& Kumar, 2017). If the employee is not rewarded enough for the role they perform, the employers will be unable to get the required performance from their employees and lose their employees. It will also become hard for them to acquire new top talents as the word can quickly spread about the company's unsatisfied work environment among the employees working in the same industry. 
Literature supports several studies carried out to derive the relationship between the total rewards and employee retention. A study conducted by Nyambura and Kamara (2017) in Kenya indicated that training and development and mentoring positively affect employee retention levels. Another study done by Al-sharafi, Hassan and Alam, (2018) revealed that training influences employee satisfaction, as well as employee retention and job satisfaction, has a substantial impact on retention and turnover. Govaerts, Kyndt., Dochy and Baert, (2011) revealed that appreciative learning and working climate have the most predictive value in terms of retention by examining both employee and individual factors. Strategic human resource practices, namely; recruitment and selection, training and career development, performance appraisal, and compensation and benefits, have a positive influence on employee retention (Fahim, 2018; Bibi et al., 2018). Organizations with supportive strategies can maintain and retain their employees for a long time (Arasanmi \& Krishna, 2019; Taylor, Garver \& Williams, 2010). Kundu and Lata (2017) have pointed out that a supportive work environment has a significant impact on employee retention than isolated practices such as perceived climate, supervisory relationship, peer-group interaction and perceived organizational support. In contrast, another study by Latha (2017) argued that salary, superior-subordinate relationship, co-worker relationship, growth opportunities, appreciation, suggestions, facilities, and procedures are all substantial motivational variables that affect employee turnover and retention. Therefore, it is observed that several non-financial rewards as well as financial rewards has been addressed in literature.

According to study carried out by Pregnolato, Bussin, and Schlechter(2010), reward elements namely; remuneration, benefits, work-life balance, performance and recognition, development and career opportunities, have a significant impact on employee retention. The social exchange theory also explains that rewards and benefits provided to employees, such as compensation, recognition, training and development, and performance appraisal, will retain the organization for a long period (Blau, 1964). As the theory says there is a mutual exchange of benefits between the employer and employee, it is also understood that when employees do not receive fair returns, they tend to leave the organization. 
Therefore, the following hypothesis is derived;

\section{H1: There is an impact of total reward perceptions on employee retention}

Literature supported the relationship between the total rewards perceptions and work engagement. According to Rai, Ghosh and Dutta (2019), by surveying employees working in Indian private sector banks, the total reward system directly relates to engagement. Some other authors (Mohapatra \& Sharma, 2010; Ram \& Prabhakar, 2011) have observed that rewards and recognition significantly influence engagement in Indian context. This is further confirmed by WorldatWork (2010) that total rewards structures, programs and policies positively impact engagement.

According to Strom, Sears and Kelly (2014), employees' engagement level depends on the perception of their rewards after accomplishing the given task. It is also found that employee rewards are essential for enhancing employees' engagement level (Gulyani\& Sharma, 2018). Recognition and rewards are significant antecedents of employee engagement (Saks \&Rotman, 2006). Juhdi et al. (2013) have proved that human resource practices such as compensation, rewards, development opportunities, career management, person-job fit, and job control influence organizational engagement. The Social Exchange theory also describes that when employees are given fair returns in terms of rewards, they are more likely to reciprocate through positive work outcomes such as work engagement (Gulyani\& Sharma, 2018).

Thus, the following hypothesis is proposed.

\section{H2: There is an impact of total reward perceptions on work engagement}

Schaufeli and Bakker (2002) have shown in their study that employee engagement is negatively related to turnover intention among employees. Hence, it can be derived that these employees have a high intent to stay. Research has demonstrated that work engagement, job satisfaction, and organizational commitment are essential antecedents for retention (Kim \& Kao, 2014). It is also confirmed by Hughes \& Rog, (2008) that employee engagement associates with important organizational outcomes relating to talent management practices such as recruitment, retention, and employee turnover. According to Malinen, Wright, and Cammock 
(2013), employees who trust senior management show higher engagement levels and lower intention to quit the organization. Similarly, it is found that high work engagement retains and motivates the employees while the absence of work engagement leads to departure from the organization (De Lange, De Witte \& Notelaers, 2008). Based on the above academic instances, the following hypothesis is proposed;

\section{H3: There is an impact of work engagement on employee retention}

Schaufeli et al. (2002) demonstrated the mediating role of work engagement between job resources and employee turnover intentions. Yalabik et al. (2013) have also suggested that work engagement partially mediates the relationships of affective commitment to better job performance and turnover intention. A study conducted by Barnes and Collier (2013) surveying the frontline employees in the service industry has indicated that job satisfaction is influenced by adaptability and career commitment, was mediated by work engagement.

Some research done in the Indian banking context has also proven the mediating role of work engagement. Findings of the study of private bank employees done by Ghosh et al. (2016) confirmed that engagement acts as a mediator between rewards and recognition and normative commitment. The mediating role of engagement between total rewards and intention to stay has also been proven in a study of employees working in the private sector in Indian banks (Rai et al., 2019). Further, Gulyani \& Sharma (2018) researched the employees in Indian technology-based new ventures and found that work engagement mediates the relation between total rewards and work happiness.

According to Airila et al. (2014), work engagement acts as a mediator between job resources (i.e. supervisor support and interpersonal relations), personal resources (i.e. self-esteem) and future work ability (i.e. employee's functional ability to perform). According to JD-R model, job resources and personal resources directly influence work engagement, affecting positive workplace outcomes such as employee retention.

Hence, the following hypothesis is derived. 
H4: Work engagement mediates the relationship between total reward perceptions and employee retention.

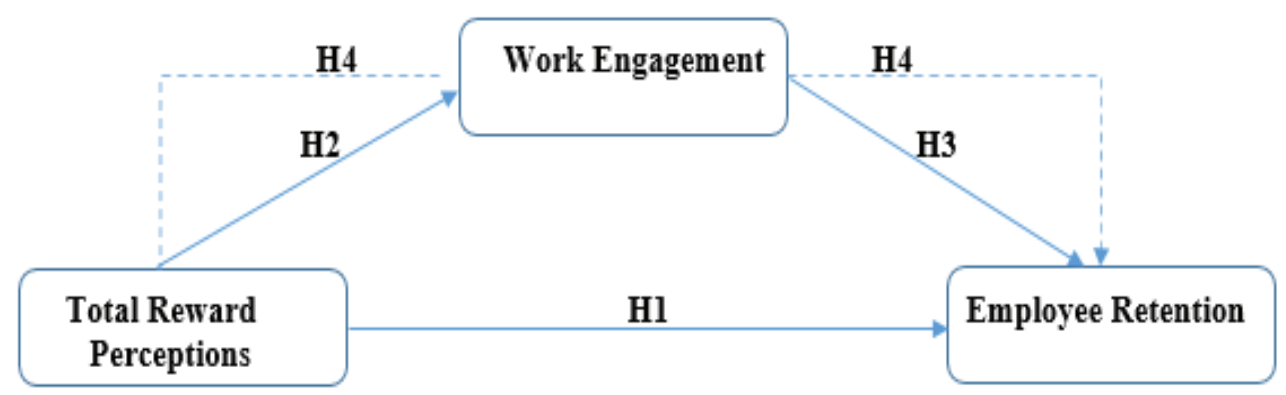

Figure 1: Conceptual Framework

Source: Authors

\section{Method}

According to the IRCSL Annual Report, 2018,26 insurance companies operate in Sri Lanka with 19,437 employees and 44,904 agents working across the country. Out of these 26 insurance companies, researchers selected three general insurance companies who are among the top 10 rankings as per the market share, targeting executive-level employees (junior executives, executives, senior executives) as the sample. This is a cross-sectional study. The unit of analysis is the individual executive-level employees in the Insurance industry. As the population which consists of executive level employees working in the three selected insurance companies is 400, the sample should consist 196 employees, according to Krejcie and Morgan (1970). The researchers employed simple random sampling technique and the data were collected through a self-administered structured questionnaire. From 196 questionnaires distributed among the respondents, the researchers gathered a sample size of 175 , which accounted for a $90 \%$ effective response rate. Then the data were tested to ensure normality, linearity, homoscedasticity, validity, reliability, correlation, and absence of multicollinearity using SPSS 20v. 


\subsection{Measures}

Total Rewards construct was measured in a ten-item five-point Likert scale designed by Hulkko-Nyman et al., (2012). The items in this scale represent mainly three areas i.e., monetary rewards (pay perceptions), material rewards (benefits perceptions), and non-monetary rewards (feedback and stability of employment and appreciated work). A sample item for monetary rewards is "How do you think the pay system functions in your company?" The scale has been validated with Cronbach's $\alpha$ ranging between 0.67 and 0.82. For work engagement, Schaufeli $\&$ Bakker (2003) designed a measurement scale of 17 items to test dimensions of vigor, dedication and absorption in a seven-point Likert scale. Some example items are "At my work, I feel bursting with energy" (vigor), "I am enthusiastic about my job" (Dedication) and "Time flies when I am working" (absorption). This scale has been extensively used in engagement research with reliabilities recorded at 0.736 and 0.815 . (Rai et al., 2019). Employee retention was measured using a four-item 5-point Likert scale designed by Daly \& Dee (2006). The reliability of this scale is 0.82 . A sample item of the measurement is "I would be reluctant to leave this company".

\subsection{Sample Composition}

The majority of the sample were males $(54.29 \%)$, while many $(71.4 \%)$ were in the age category of 26-35 years. Most of the respondents were executives, which accounts for $50.3 \%$ of the total sample. Most of the respondents had less than six years of experience, showing a percentage of $62.28 \%$. Further, only $37.72 \%$ of respondents worked for more than six years, while only $15.43 \%$ served in the same organization for more than ten years. Work experience results indicated that there is an issue of retaining employees in this industry.

\section{Results}

The reliability of the data was tested using alpha coefficient values. All three scales have Cronbach's alpha values greater than 0.7 and over. Hence, the items formed a scale of reasonable internal consistency in reliability. The researchers 
used KMO (Kaiser-Meyer-Olkin) and Bartlett's test to measure validity. As all the KMO values were greater than 0.5 and the significance values of the Bartlett's test were 0.000 meaning the factors that form the variables were satisfactory. To examine the normality of the variables, both skewness and kurtosis were assessed. According to Kline (2005), if the variable has a skew index of absolute value less than 03 and kurtosis value less than 10, then the data are sufficiently normally distributed for that variable. The results of this test implied that the data of the study were normally distributed. Linear scatter plots were used to test the linear relationship between the variables used in the study and it was shown that there is a positive linear relationship between the three variables. Further, as the Variance Inflation Factor (VIF) for each variable is less than 10 (Field, 2009), no multicollinearity exists between the variables.

The mean, Standard Deviation (SD), correlation, and reliability statistics related to the model variables are shown in Table I.

Table 1: Descriptive Statistics and Output of the Preliminary Analysis

\begin{tabular}{|l|c|c|c|c|c|c|}
\hline Variable & Mean & $\begin{array}{c}\text { Standard } \\
\text { Deviation }\end{array}$ & 1 & 2 & 3 & $\begin{array}{c}\text { Cronbach } \\
\text { Alpha }(\alpha)\end{array}$ \\
\hline $\begin{array}{c}\text { 1. Total } \\
\text { Rewards }\end{array}$ & 3.246 & 0.645 & - & & & 0.864 \\
\hline $\begin{array}{c}\text { 2. Work } \\
\text { Engagement }\end{array}$ & 4.325 & 1.002 & $.789^{* *}$ & - & & 0.934 \\
\hline $\begin{array}{c}\text { 3. Employee } \\
\text { Retention }\end{array}$ & 2.956 & 0.703 & $.617^{* *}$ & $.665^{* *}$ & - & 0.700 \\
\hline
\end{tabular}

**. Correlation is significant at the 0.01 level (2-tailed).

Source: Survey Data, 2020

According to Table I, the mean value of 3.246 indicates a moderate level of total rewards perceptions, which is also the same for the retention intention $($ mean $=2.956)$ and work engagement (mean $=4.325$ of 7 points Likert scale). Correlation coefficient figures indicate strong positive correlations among 
the variables. The scales' internal consistency reliabilities were also met with Cronbach alpha values above 0.7 for all the variables.

\subsection{Hypotheses testing}

There are four hypotheses tested in this study. The first three hypotheses test the direct relationship between the variables total rewards, work engagement, and employee retention, whereas the fourth hypothesis tested the mediating effect of work engagement on total rewards and employee retention. Linear Regression analysis is used to test the direct relationships that exist between the variables, while the mediating impact has been tested using the Sobel test.

Table 2: Results of Regression Analysis

\begin{tabular}{|c|c|c|c|c|c|c|c|c|c|}
\hline & \multicolumn{3}{|c|}{$\begin{array}{l}\text { Total rewards perception } \\
\text { on employee retention }\end{array}$} & \multicolumn{3}{|c|}{$\begin{array}{l}\text { Total reward perceptions on } \\
\text { work engagement }\end{array}$} & \multicolumn{3}{|c|}{$\begin{array}{l}\text { Work engagement on } \\
\text { employee retention }\end{array}$} \\
\hline & $\beta$ & $\mathrm{T}$ & Sig & B & $\mathrm{T}$ & Sig & B & $\mathrm{T}$ & Sig \\
\hline $\begin{array}{l}\text { Independent } \\
\text { Variable }\end{array}$ & 0.672 & 10.299 & 0.000 & 1.226 & 16.896 & 0.000 & 0.935 & 5.288 & 0.000 \\
\hline $\mathrm{R}^{2}$ & 0.380 & & & 0.623 & & & 0.443 & & \\
\hline Adjusted $\mathrm{R}^{2}$ & 0.377 & & & 0.620 & & & 0.440 & & \\
\hline$\Delta \mathrm{F}$ & 106.074 & & & 285.478 & & & 137.531 & & \\
\hline Sig. $\Delta \mathrm{F}$ & 0.000 & & & 0.000 & & & 0.000 & & \\
\hline
\end{tabular}

Source: Survey Data, 2020

According to the model summary statistics presented in Table II, the R2, which is the explained variance, is $38 \%$. The $F$ change statistics produced ( $F=106.074)$ is significant at .000 . The first objective of the study is to investigate the impact of total reward perceptions on employee retention. The regression results confirm that the relationship between total reward perceptions on employee retention is significant. The beta value of 0.672 is positive, concluding the relationship is positive. The P-value is 0.00 , which is less than 0.05 and therefore the relationship is significant. Hence, H1 is supported. 
According to the model summary statistics presented in table II, the R2, which is the explained variance is $62.3 \%$ The $F$ change statistics produced $(F=285.478)$ is significant at 0.000 . Results suggests that the influence of total rewards on work engagement is significant. This output represents that the independent variable total rewards explain $62.3 \%$ variance (R2 value) in work engagement. Further, the Beta value 1.226 is positive at a significance level of 0.01 , indicating the positive relationship between total rewards and work engagement. Therefore, it could be confirmed that there is a significant impact of total rewards on work engagement. Hence, $\mathrm{H} 2$ is supported.

As per table II, the R2, which is the explained variance, is $44.3 \%$. The $F$ change statistics produced $(F=137.531)$ is significant at 0.000 . This suggests that the influence of work engagement on employee retention is significant. $44.3 \%$ variance ( $R 2$ value) in work engagement is explained by the independent variable total rewards. Further, the Beta value of 0.935 is positive at a significance level of 0.01 , indicating the positive relationship between work engagement and employee retention. Hence, $\mathrm{H} 3$ is also supported.

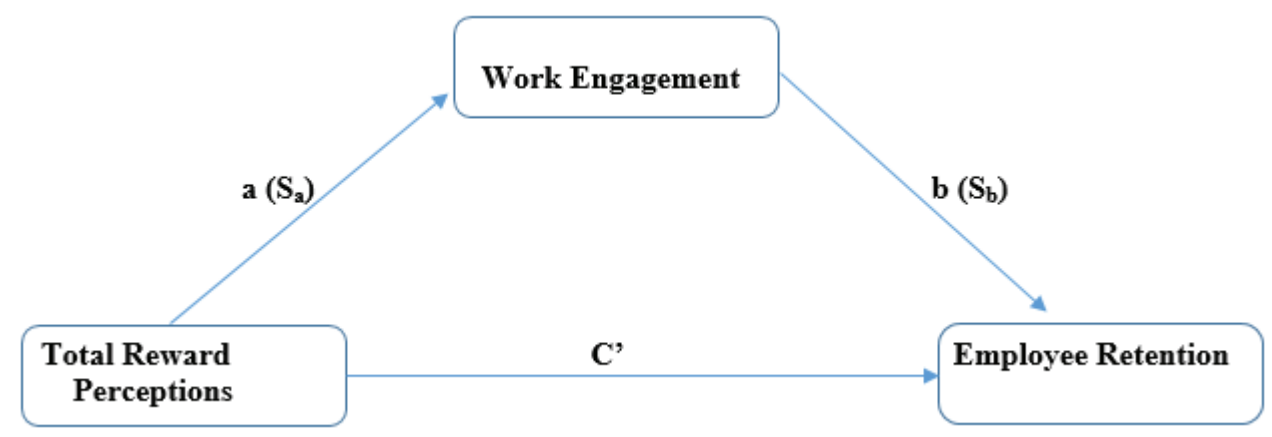

Figure 2: Simple Mediation Model

Source: Authors, 2020

The results of hypothesis 2 and the following results presented in table III, of the relationship between the mediator work engagement and dependent variable employee retention when the independent variable total reward perceptions also act as a predictor of the dependent variable is used as the input for sobel test. 


\section{Table 3: The Mediating Impact of Work Engagement}

Independent Variable Total Rewards Perceptions Work Engagement

Employee Retention

$\mathrm{B}$

0.264

0.333

$\mathrm{T}$

2.667

5.225

Sig

0.008

0

Standard Error

0.099

0.064

$\mathrm{R}^{2}$

0.465

Adjusted $\mathrm{R}^{2}$

$\Delta \mathrm{F}$

0.459

Sig. $\Delta \mathrm{F}$

74.753

Source: Survey Data, 2020

Researchers used an online Sobel test calculator to identify the mediating effect of work engagement. Figure I has visualized the result of the conducted Sobel test.

\begin{tabular}{|c|c|c|c|c|}
\hline Input: & & Test statistic: & Std. Error: & $p$-value: \\
\hline a 1.226 & Sobel test: & 4.97006874 & 0.08214333 & $6.7 e-7$ \\
\hline$b 0.333$ & Aroian test: & 4.96204935 & 0.08227609 & $7 e-7$ \\
\hline$s_{a} 0.073$ & Goodman test: & 4.97812714 & 0.08201036 & $6.4 e-7$ \\
\hline$s _ { \mathrm { b } } \longdiv { 0 . 0 6 4 }$ & Reset all & & Calculate & \\
\hline
\end{tabular}

\section{Figure 3: Sobel test results}

Source: Authors, 2020

According to Figure III, the test statistic for the Sobel test is 4.97 , with an associated p-value of 0.00000067 . The fact that the observed p-value is below the established alpha level of 0.05 . The Sobel test results indicate that the association between the independent variable total reward perceptions and the dependent variable is partially affected by work engagement. Therefore, it could be explained that there is a partial mediation of work engagement between total reward perceptions and employee retention. Hence, H4 is supported. 


\section{Discussion}

According to the results, $\mathrm{H} 1$ is supported, indicating a significant impact of total reward perceptions on employee retention. Hence, the researchers can conclude that employees who receive a fair return on their efforts in work in terms of rewards are more likely to stay with the employer for a long time. The total reward perception addressed in the study includes monetary rewards (i.e. pay system), material rewards (i.e. benefits, training and development possibilities) and non-monetary rewards (i.e. feedback, decision making, time arrangement, stability of employment, challenging work and appreciated work). The study results are related to Akhtar et al. (2015)'s findings, which state that both total reward and retention have a significant and robust relationship. The studies conducted by Fahim (2018) and Bibi et al. (2018) also stated that training and career development, performance appraisal, and compensation and benefits positively influence employee retention. This relationship is also supported by the social exchange theory explaining mutual exchange of benefits. When the employees are fairly rewarded they will remain with the firm for a more extended period.

Further, H2 is supported for the significant impact of total reward perceptions on work engagement. The results are consistent with Rai et al. (2019) study, which mentions that the total reward system directly relates to work engagement. Gulyani and Sharma (2018) have also found that employee rewards are essential for enhancing employees' engagement levels. Schaufeli (2013), as per his study, also states that the organization's resources such as decent pay, recognition, and training and development opportunities, engage the employee at work.

When it comes to $\mathrm{H} 3$, which supports the significant impact of work engagement on employee retention, is in line with the study of De Lange et al. (2008), which reveals that high work engagement retains and motivate the employees while the absence of work engagement leads to the departure of employees from the organization. Shuck et al. (2011) suggested that employee retention can be increased by work engagement. 
Finally, H4 supported the mediating role of work engagement between total rewards perceptions and work engagement. In other words, work engagement mediates the proposed hypothesized relationship between total reward perceptions and employee engagement. This is consistent with Rai et al. (2019), who established the mediating role of engagement between total rewards and intention to stay. The findings also support the JD-R model. Human resource practices such as total rewards perceptions can influence work engagement, resulting in positive workplace outcomes as employee retention.

\section{Conclusion and Recommendations}

The present study tested four hypotheses. The first three hypotheses were tested to investigate whether there is a direct relationship between total reward perceptions, work engagement and employee retention. These hypotheses were supported, showing a significant impact between the three variables. It reveals that when employees receive fair returns they are willing to stay with the organization for longer period. Further, it was also found that total rewards play an essential role in enhancing the employees' engagement level. The study shows that high work engagement increases the retention of employees. The fourth hypothesis supported the mediating effect of work engagement between total reward perceptions and employee retention.

The findings suggest that employees working in insurance companies are engaged with work when they are satisfied with appropriate rewards. Total rewards should include monetary, material, and non-monetary rewards to build a more committed workforce. Therefore, special attention should be given to enhancing the material rewards such as pay and material and non-monetary rewards such as benefits, training and development opportunities, positive work environment, challenging work, appreciation of work, job security, etc.

The study has supported the mediation of work engagement on total rewards perceptions and employee retention. Hence, it is understood that the management of any organization should give more attention to making their employees engaged with work by providing appropriate rewards, which will help the employer retain employees for longer period. Hence, the current study generates new knowledge 
to the existing literature in work engagement, revealing its mediation effect on the relationship between total rewards perceptions and employee retention.

The research findings show that high-level employee turnover is costly for any organization in terms of financial costs and non-financial terms such as time involved to recruit and train a new employee. When considering the insurance industry, organizations losing their talented employees to competitors is a major issue as they take the knowledge gained over the years of employment. Hence, employee retention is beneficial for the management of the company as well as the employees. Therefore, the following mentioned recommendations can be made to retain the employees with the organizations. Employers should adopt a total reward strategy where employees receive the return in terms of monetary, material and non-monetary rewards. Hence, in addition to the base pay, the employer should provide benefits to the employees as health care, life insurance, vacations, sick leave, and perquisites such as country club memberships. The management should also provide better working conditions, appropriate training and development, provide meaningful and challenging work, and appreciate work and recognition.

\section{Limitations}

The research was conducted considering the executive category employees working in only three insurance companies in Sri Lanka. The present study was also performed as a cross-sectional study as data were collected at one point in time. Moreover, the researcher has only used the survey method to collect the data and a sample consisting 196 employees was used for the research purposes. As this study has been carried out in an insurance context the results represent a single context only.

\section{Future Research Directions}

Future research can extend to other public and private insurance companies to arrive at more generalized and accurate findings of the impact of total reward perceptions on employee retention. Also, the study can be further conducted by surveying the employees of other designation levels. It is suggested to carry out 
longitudinal studies in the future. Researchers can use alternative measures such as open-ended interviews and gather data from employees who have resigned from the organization. Future studies can be conducted in different contexts to help the researchers understand the impact of total reward on employee retention and the mediator work engagement in other industries. Besides, studies should also involve more expansive geographical areas as well as larger sample sizes. 


\section{References :}

Agus, A., \& Selvaraj, R. (2020). The mediating role of employee commitment in the relationship between quality of work life and the intention to stay. Employee Relations: The International Journal.42(06). 1232-1248.

Ahammad, M. F., Glaister, K. W., Weber, Y., \&Tarba, S. Y. (2012). Determinants of top management retention in cross border acquisitions. In Handbook of Research on Mergers and Acquisitions. Edward Elgar Publishing, 10(2), 259-282.

Airila, A., Hakanen, J. J., Schaufeli, W. B., Luukkonen, R., Punakallio, A., \&Lusa, S. (2014). Are job and personal resources associated with work ability 10 years later? The mediating role of work engagement. Work \& Stress, 28(1), 87-105.

Akhtar, C. S., Aamir, A., Khurshid, M. A., Abro, M. M. Q., \& Hussain, J. (2015). Total rewards and retention: Case study of higher education institutions in Pakistan. Procedia-Social and Behavioral Sciences, 210(2015), 251-259.

Albrecht, S. L. (2010). Employee engagement: 10 key questions for research and practice. In S. L. Albrecht (Ed.), New horizons in management. Handbook of employee engagement: Perspectives, issues, research and practice, 3-19

Al-sharafi, H., Hassan, M. E. M., \&Alam, S. S. (2018). The Effect of Training and Career Development on Employees Retention â€"A Study on the Telecommunication Organizations in Yemen. The Journal of Social Sciences Research, 420-430.

Arasanmi, C. N., \& Krishna, A. (2019). Employer branding: perceived organisational support and employee retention-the mediating role of organisational commitment. Industrial and Commercial Training, 51(3), 174-183.

Bansal, S. (2014), "Employee retention strategies", International Journal of Research in Management and Social Science, 22(1), 62-85.

Barnes, D. C., \& Collier, J. E. (2013). Investigating work engagement in the service environment. Journal of Services Marketing, 27(6), 485-499. 
Bibi, P., Ahmad, A., \& Majid, A. H. (2018). HRM practices and employee retention: The moderating effect of work environment. Applying partial least squares in tourism and hospitality research, 129-152.

Blau, P. M. (1964). Justice in social exchange. Sociological inquiry, 34(2), 193-206.

Chitsaz-Isfahani, A., \&Boustani, H. R. (2014). Effects of talent management on employees retention: The mediate effect of organizational trust. International Journal of Academic Research in Economics and Management Sciences, 3(5), 114-135.

Crawford, E. R., Rich, B. L., Buckman, B., \& Bergeron, J. (2014). The antecedents and drivers of employee engagement. Employee engagement in theory and practice, 44(6), 57-81.

Daly, C. J., \& Dee, J. R. (2006). Greener pastures: Faculty turnover intent in urban public universities. The Journal of Higher Education, 77(5), 776-803.

De Gieter, S., De Cooman, R., Pepermans, R., Caers, R., Du Bois, C., \&Jegers, M. (2006). Identifying nurses' rewards: a qualitative categorization study in Belgium. Human Resources for health, 4(15), 1-8

De Lange, A. H., De Witte, H., \&Notelaers, G. (2008). Should I stay or should I go? Examining longitudinal relations among job resources and work engagement for stayers versus movers. Work \& Stress, 22(3), 201-223.

Dhanalakshmi, R. V., Gurunathan, K. B., \& Vijayakumar, M. (2016). A study on talent management practices and its impact on employee retention in IT industry in Chennai district. Asian Journal of Research in Social Sciences and Humanities, 6(9), 916-929.

Din, S. M. U., Abu-Bakar, A., \&Regupathi, A. (2017). Does insurance promote economic growth: A comparative study of developed and emerging/ developing economies. Cogent Economics \& Finance, 5(1), 1390029. 
Earnest, D. R., Allen, D. G., \& Landis, R. S. (2011). Mechanisms linking realistic job previews with turnover: A meta-analytic path analysis. Personnel Psychology, 64(4), 865-897.

Fahim, M. G. A. (2018). Strategic human resource management and public employee retention. Review of Economics and Political Science, 3 (2), 20-39.

Field, A. (2009). Discovering statistics using SPSS:(and sex and drugs and rock'n'roll). Sage.

Fletcher, L., Alfes, K., \& Robinson, D. (2018). The relationship between perceived training and development and employee retention: the mediating role of work attitudes. The International Journal of Human Resource Management, 29(18), 2701-2728.

Gavino, M. C., Wayne, S. J., \& Erdogan, B. (2012). Discretionary and transactional human resource practices and employee outcomes: The role of perceived organizational support. Human Resource Management, 51(5), 665-686.

Govaerts, N., Kyndt, E., Dochy, F., \&Baert, H. (2011). Influence of learning and working climate on the retention of talented employees. Journal of workplace learning, 23(1), 35-55.

Gulyani, G., \& Sharma, T. (2018, December). Total rewards components and work happiness in new ventures. In Evidence-based HRM: a Global Forum for Empirical Scholarship. Emerald Publishing Limited, 6(3), 255-271.

Heneman, R. L., \&Tansky, J. W. (2002). Human resource management models for entrepreneurial opportunity: Existing knowledge and new directions. Managing people in entrepreneurial organizations, 5, 55-82.

Hughes, J. C., \& Rog, E. (2008). Talent management: A strategy for improving employee recruitment, retention and engagement within hospitality organizations. International Journal of Contemporary Hospitality Management, 20(7), 743-757. 
Hulkko-Nyman, K., Sarti, D., Hakonen, A., \&Sweins, C. (2012). Total rewards perceptions and work engagement in elder-care organizations: findings from Finland and Italy. International Studies of Management \& Organization, 42(1), 24-49.

IRCSL Annual Report (2018). Insurance Regulatory Commission of Sri Lanka retrieved from https://ircsl.gov.lk/wp-content/uploads/2020/09/IBSLAR-English-2018-Fullset.pdf

Jayatilake, L. \& Gamage, S K. (2017). An Investigation of the Employee Satisfaction and Organizational Commitment on Employee Job Retention in Selected Insurance Companies in Sri Lanka. International Journal of Scientific Research and Innovative Technology, 4(10), 2313-3759.

Jiang, Z., Xiao, Q., Qi, H., \& Xiao, L. (2009). Total reward strategy: A human resources management strategy going with the trend of the times. International Journal of Business and management, 4(11), 177-183.

Juhdi, N., Pa'wan, F., \&Hansaram, R. M. K. (2013). HR practices and turnover intention: the mediating roles of organizational commitment and organizational engagement in a selected region in Malaysia. The International Journal of Human Resource Management, 24(15), 3002-3019.

Kahn, W. A. (1990). Psychological conditions of personal engagement and disengagement at work. Academy of management journal, 33(4), 692-724.

Kim, H., \& Kao, D. (2014). A meta-analysis of turnover intention predictors among US child welfare workers. Children and Youth Services Review, 47(3), 214-223.

Krejcie, R. V., \& Morgan, D. W. (1970). Determining sample size for research activities. Educational and psychological measurement, 30(3), 607-610.

Kumar, D., \& Clerk, D. (2020). Employee Retention: A Study of Indian Insurance Industry. Employee Retention: A Study of Indian Insurance Industry (June 30, 2020). 
Kundu, S. C., \& Lata, K. (2017). Effects of supportive work environment on employee retention. International Journal of Organizational Analysis, 25(4). 703-722.

Malinen, S., Wright, S., \& Cammock, P. (2013). What drives organizational engagement. Evidence-based HRM, 1(1), 96-108.

Mathimaran, K. B., \& Kumar, A. A., (2017). Employee retention strategies: An empirical research. Global Journal of Management and Business Research, 17(1), 17-19.

Medcof, J. W., \&Rumpel, S. (2007). High technology workers and total rewards. The Journal of High Technology Management Research, 18(1), 59-72.

Mendis, K., Silva, D. A. C., \& Mitsuhashi, I. (2009). An examination of economic impact of employee turnover and retention: special reference to the insurance industry of Sri Lanka, 39-54.

Mohapatra, M., \& Sharma, B. R. (2010). Study of employee engagement and its predictors in an Indian public sector undertaking. Global business review, 11(2), 281-301.

Mustafa, G., \& Ali, N. (2019). Rewards, autonomous motivation and turnover intention: Results from a non-Western cultural context. Cogent Business \& Management, 6(1), 1676090.

Nyambura, N., \& Kamara, J. (2017). Influence of Career Development Practices on Employee Retention in Public Universities-A Case of Technical University of Kenya. Journal of Strategic Business and Change Management, 4(30), 510-522.

O'Neal, S. (1998). The phenomenon of total rewards. The Journal of Total Rewards, 7(3), 6-18

Paillé, P. (2013). Organizational citizenship behaviour and employee retention: how important are turnover cognitions?. The International Journal of Human Resource Management, 24(4), 768-790. 
Pattanayak, S., \& Chhabra, B. (2014). The impact of perceived organizational support on job satisfaction, affective commitment, turnover intentions and organizational citizenship behavior: a study of insurance sector. IJLTEMAS, 3(7), 78-87.

Peluso, A. M., Innocenti, L., \&Pilati, M. (2017, December). Pay is not everything. In Evidence-based HRM: A Global Forum for Empirical Scholarship. Emerald Publishing Limited, 5(3), 311-327

Prabhakar, G. V., \& Ram, P. (2011). Antecedent HRM practices for organizational commitment. International journal of business and social science, $2(2), 55-62$.

Pregnolato, M., Bussin, M. H., \&Schlechter, A. F. (2017). Total rewards that retain: A study of demographic preferences. SA Journal of Human Resource Management, 15(1), 1-10.

Rai, A., Ghosh, P., \& Dutta, T. (2019, December). Total rewards to enhance employees' intention to stay: does perception of justice play any role? In Evidence-based HRM: a Global Forum for Empirical Scholarship. Emerald Publishing Limited.

Rasika, D. G. L., Sanjeewa,W.S., Perera, T (2016)Evaluating the factors influencing the Retention of Insurance Agents: A case study on Life Insurance Industry in Sri Lanka. Belihuloya, Faculty of Management Studies, Sabaragamuwa university of Sri Lanka

Redditt, J., Gregory, A. M., \& Ro, H. (2019). An examination of organizational commitment and intention to stay in the timeshare industry: variations across generations in the workplace. International Journal of Hospitality \& Tourism Administration, 20(2), 206-225.

Saks, A. M. (2006). Antecedents and consequences of employee engagement. Journal of managerial psychology, 21 (7), 600-619. 
Schaufeli, W. B., Salanova, M., González-Romá, V., \& Bakker, A. B. (2002). The measurement of engagement and burnout: A two sample confirmatory factor analytic approach. Journal of Happiness studies, 3(1), 71-92.

Schaufeli, W.B. (2013). What is engagement? In C. Truss, K. Alfes, R. Delbridge, A. Shantz, \& E. Soane (Eds.), Employee Engagement in Theory and Practice. London: Routledge.

Sheehan, M. (2012). Developing managerial talent: Exploring the link between management talent and perceived performance in multinational corporations (MNCs). European Journal of Training and Development, 36(1), 66-85.

Shuck, B., Twyford, D., Reio Jr, T. G., \& Shuck, A. (2014). Human resource development practices and employee engagement: Examining the connection with employee turnover intentions. Human Resource Development Quarterly, 25(2), 239-270

Sinha, C., \& Sinha, R. (2012). Factors affecting employee retention: A comparative analysis of two organizations from heavy engineering industry. European journal of business and management, 4(3), 145-162.

Strom, D. L., Sears, K. L., \& Kelly, K. M. (2014). Work engagement: The roles of organizational justice and leadership style in predicting engagement among employees. Journal of leadership \& organizational studies, 21(1), 71-82.

Taylor, G.S., Garver, M.S. and Williams, Z. (2010), “Owner operators: employing a segmentation approach to improve retention", The International Journal of Logistics Management, 21(2), 207-229.

Thite, M. (2010). All that glitters is not gold: Employee retention in offshored Indian information technology enabled services. Journal of Organizational Computing and Electronic Commerce, 20(1), 7-22.

World atWork (2010), "The relative influence of total rewards elements on attraction, motivation, and retention", March, retrieved from: 
www.worldatwork.org/docs/research-and-surveys/worldatworks ponsored-research/research-report-the-relative-influence-of-totalrewardselements-on attraction- motivation-and-retention.pdf (accessed April 1, 2018).

Yalabik, Z. Y., Popaitoon, P., Chowne, J. A., \&Rayton, B. A. (2013). Work engagement as a mediator between employee attitudes and outcomes. The International Journal of Human Resource Management, 24(14), 2799-2823. 